\title{
BENIGN BREAST DISEASES IN NORTH CHENNAI WOMEN POPULATION
}

B.V. Sreedevi ${ }^{1}$

\section{HOW TO CITE THIS ARTICLE:}

B.V. Sreedevi. "Benign Breast Diseases in North Chennai Women Population". Journal of Evolution of Medical and Dental Sciences 2014; Vol. 3, Issue 03, January 20; Page: 754-757, DOI:10.14260/jemds/2014/1897

ABSTRACT: Benign breast disease is more common prevailing condition among women population than cancer breast. About half of the women population suffers from benign breast diseases in their life time. A tendency to hide or unveil the complaints about the breast among the Indian women population has led to decreased statistics and hence this study was conducted. Method: Cross sectional analysis of the women who attended outpatient department were taken into study. 200 patients who attended outpatient with breast complaints were examined and analyzed. Result: 110 patients presented with mastalgia, 86 patients presented with breast mass, 14 patients presented with nipple discharge. Of these, 110 patients were further evaluated and found out the cause of mastalgia. Conclusion: Non-cyclical mastalgia was found to be the commonest presentation among the breast complaints.

KEY WORDS: Benign Breast Disease, Cyclical Mastalgia, Ductectasia, Cyst, Fine Needle Aspiration Cytology (FNAC)

INTRODUCTION: Benign Breast diseases are at least 10 times more common than breast cancer in the west ${ }^{1}$. A tendency to hide health problem among the Indian women population and reluctance to reveal about the breast problem to general practitioners had led to the decrease in the statistics. Hence aim of the study was to profile the incident and spectrum of BBD among north Chennai women population examined on an outpatient basis and without a biopsy for a more realistic appraisal of its incidence. For the attitude of doctors and patients, BBD was ignored and hence this study was conducted. MATERIALS AND METHODS: About 200 patients were examined under the care of the author who presented with breast $\mathrm{C} / \mathrm{O}$ and details regarding the Age, Duration of symptoms, History of trauma, Menstrual H/O, Lactation H/O, USG Examination, Menopause and FNAC. The parameters of data gathered reflect breast specific history taking and clinical examination of the breasts.

Clinical examination and clinical diagnosis was recorded solely by the author to eliminate variations in clinical assessment of multiple observers. Information from mammography, Fine needle aspiration cytology, old operation notes and HPE report were utilized when available to corroborate clinical diagnosis.

Results: Of 200 patients examined:

110 patients presented with Breast Pain (Mastalgia)

86 patients presented with Breast mass

14 patients presented with Nipple discharge

Only patients who presented with Mastalgia were taken in to consideration and further study.

Further study of these mastalgia patients were taken and clinical H/O, clinical examination, USG, mammograms, FNAC were done. 


\begin{tabular}{|c|c|c|c|c|c|}
\hline \multicolumn{6}{|c|}{ Statistical Analysis } \\
\hline \multicolumn{2}{|c|}{ Disease } & & $\begin{array}{c}\text { No of } \\
\text { Patients }\end{array}$ & Duration & Age \\
\hline $\begin{array}{l}\text { Cyclical } \\
\text { Mastalgia (72) }\end{array}$ & Fibroadenosis & & 30 & \multirow[b]{3}{*}{$\begin{array}{l}10-20 \\
\text { months }\end{array}$} & \multirow[b]{3}{*}{$18-38$} \\
\hline & Cystic Disease & & 7 & & \\
\hline & $\begin{array}{l}\text { Only Cyclical } \\
\text { Mastalgia }\end{array}$ & & 35 & & \\
\hline \multirow[t]{4}{*}{$\begin{array}{l}\text { Non-cyclical } \\
\text { Mastalgia (18) }\end{array}$} & $\begin{array}{l}\text { Non-Cyclical } \\
\text { Mastalgia }\end{array}$ & & 7 & \multirow{6}{*}{$\begin{array}{c}10-20 \\
\text { days }\end{array}$} & \multirow{4}{*}{$\begin{array}{l}9 \text { to } 11 \text { years }-5 \text { patients } \\
11 \text { to } 18 \text { years }-1 \text { patient }\end{array}$} \\
\hline & Fibro Adenoma & & 4 & & \\
\hline & \multirow{2}{*}{ Mastitis } & $\begin{array}{c}\text { Nonlactating } \\
\text { Mastitis (2) }\end{array}$ & \multirow{2}{*}{$\begin{array}{l}2 \\
5\end{array}$} & & \\
\hline & & $\begin{array}{c}\text { Lactating } \\
\text { Mastitis (5)* }\end{array}$ & & & \\
\hline & \multirow{2}{*}{$\begin{array}{l}\text { Lactating } \\
\text { Mastitis(5)* }\end{array}$} & $\begin{array}{c}\text { Lactating } \\
\text { Mastitis (1) }\end{array}$ & \multirow{2}{*}{$\begin{array}{l}1 \\
4\end{array}$} & & \multirow{2}{*}{$\begin{array}{l}\text { Above } 40 \text { years }-2 \\
\text { patients }\end{array}$} \\
\hline & & Abscess (4) & & & \\
\hline
\end{tabular}

RESULTS: Cyclical mastalgia patients were 72 (65\%) and non-cyclical mastalgia patients were 18 (16\%). In cyclical mastalgia fibroadenosis patients were 30 (42\%), Cystic diseases were 7 (10\%) and only cyclical mastalgia were 35 (49\%). In noncyclical mastalgia fibroadenoma were 4 (22\%), Mastitis were 7 (39\%) and in this non lactating mastitis 2 (28\%), lactating mastitis 5 (71\%) and in this which turned in to Abscess were 4 (80\%).

Regarding the duration of symptoms, cyclical mastalgia present for 10-20 months (Average 15 months). Non-Cyclical Mastalgia present for 10-20 days (Average 15 days).

Regarding the age cyclical mastalgia presented in the age group of 18-38 and Non-Cyclical Mastalgia presented in the age group of 9 to 11 years -5 patients, 11 to 18 years -1 patient, 18-40 years - 10 patient, Above 40 years - 2 patients.

Regarding past $\mathrm{H} / \mathrm{O}$ of breast disease: 2 patients in the cyclical mastalgia group presented with previous $\mathrm{H} / \mathrm{O}$ Fibro adenoma surgery

Family $\mathrm{H} / \mathrm{O}$ of breast disease: 7 patients in cyclical mastalgia group gave a family $\mathrm{H} / \mathrm{O}$ of breast cancer in their mothers and all these has occurred over the age of 50 years.

Menstrual and obstetrics profile: 19 patients with cyclical mastalgia gave a history of menstrual irregularity. 25 patients with cyclical mastalgia were premenopausal. Only 2 patients of cyclic mastalgia have undergone MTP. No patients of Non-Cyclical Mastalgia gave H/O of abortion. 
DISCUSSION: Benign Breast Disease: This is the most common cause of breast problem - up to $30 \%$ of women will suffer from benign breast disorder requiring treatment at some time in their lives. The most common symptoms are pain, lumpiness or a lump. The aim of treatment is to exclude cancer and once this has been done to treat any remaining symptoms.

Benign breast disorders can be classified ${ }^{2}$ in the following way:

1) Aberrations of normal development and involution (ANDI) (3) - Cyclical mastalgia with nodularity, fibroadenoma, cyst.

2) Ductectasia, Periductal mastitis

3) Pregnancy related - Galactocele, puerperal abscess

4) Congenital disorders - inverted nipple, supernumary nipple

5) Non breast disease - Sebaceous cysts, Tietze's disease

AND1: The pathogenesis of AND1 involves the hormonal disturbances the breast undergoes during every menstrual cycle. There is no correlation between the histological appearance of the breast tissue and the symptoms. The histopathology appearance is as follows.

It can be cyst formation, fibrosis, hyperplasia of epithelium, and papillomatosis.

\begin{tabular}{|l|l|l|}
\hline \multicolumn{1}{|c|}{ AND13 $^{-}$} & \multicolumn{1}{c|}{ Normal } & \multicolumn{1}{c|}{ Aberration } \\
\hline \multirow{2}{*}{ Early reproduction age group (15-25) } & Lobule formation & Fibro adenoma \\
\cline { 2 - 3 } & Stroma Formation & Juvenile Hypertrophy \\
\hline Reproduction age group (25-40) & Lobules and stroma & Cyclical Mastalgia with nodularity \\
\hline \multirow{3}{*}{ Involution (35-55) } & Lobules & Cysts, Sclerosing adenosis \\
\cline { 2 - 3 } & Ductal Involvement & Ductal dilation \\
\cline { 2 - 3 } & Epithelial Tissue & Mild epithelial hyperplasia \\
\hline
\end{tabular}

Fibroadenoma: It is a benign tumor of one lobule. It can be a pericanalicular type or intra canalicular type. The peak age incidence is 20 years. The fibroadenoma is a smooth round bordered firm to hard in consistency and freely mobile within breast.

Fibroadenosis: This is more common. It is an aberration of normal changes in breast. Presents as premenstrual pain.

Treatments: 1) Reassurance

2) Evening Prim rose oil

3) Danazol

4) Tamoxifen

Treatment of Fibroadenoma: 1) Reassurance

2) Surgery is done when it is $>5 \mathrm{~cm}$ or patient choice.

Breast infections ${ }^{4}$ : Can be lactational, non lactational. 
Lactational: During the puerperal period while breast feeding the nipples are prone for cracking permitting the entry of S.aureus into duet system. The breast milk acts as a culture medium allowing development of mastitis or breast abscess formation.

Treatment consists of promoting breast milk flow by either expression or continued breast feeding with early antibiotic treatment. If an abscess has developed than repeated ultrasound guided aspiration of pus should be performed.

Non lactational: These infections are usually periareolar and require antibiotic treatment.

CONCLUSION: Benign breast conditions form the greatest proportion of the new referrals to outpatients. Of all the complaints, non-cyclical mastalgia was found to be most common presentation of the benign breast disease. These patients, regardless of age, are commonly extremely worried about the underlying cause for their symptoms. Knowledge of the development of the breast in addition to its normal cyclical variation and involution is extremely helpful in understanding the pathologies that might develop. The AND1 and non AND1 classification is a helpful framework upon which to diagnose benign breast pathology. The key to evaluation of all breast disease is triple assessment of all breast disease with careful examination, appropriate imaging to visualize abnormality in the breast at all ages and core biopsy where appropriate. The multidiscipline team plays a pivotal role in both diagnosis and management. ${ }^{4}$

\section{References:}

1. Uma Krishnaswamy. Profile of Benign Breast Diseases in Urban India, Indian Journal of Surgery, March-April 2003; 65; 178-81 (Internet) (cited 2013 Oct 21) available from www.bioline.org.br

2. RCG Russell, NS Williams, CJK Bulstrode, editor. Bailey and Love's short practice of surgery, 23rd ed. London: Arnold: 2000. P 755-60.

3. CMK Reddy, JS Rajkumar. Reddy and Rajkumar's Short Cases in Surgery. $2^{\text {nd }}$ ed. New Delhi. CBS Publishers and Distributors: 2013 P.565-75

4. Shraddha Datta, Elerilyold Davies, Benign Breast Diseases Surgery (Oxford) Jan 2013: 31: 226: (Internet) cited on2013 Oct 23 available on journals. Ohiolink.edu./ejc/search

\section{AUTHORS:}

1. B.V. Sreedevi

\section{PARTICULARS OF CONTRIBUTORS:}

1. Associate Professor, Department of Surgery, Tagore Medical College and Hospital, Rathinamangalam, Kanchipuram District.

\section{NAME ADDRESS EMAIL ID OF THE} CORRESPONDING AUTHOR:

Dr. B.V. Sreedevi, \#3, Gnanambal Garden, II ST, Ayanauaram, Chennai.

Email-durgeonsreedevi@gmail.com

Date of Submission: 27/12/2013.

Date of Peer Review: 28/12/2013.

Date of Acceptance: 03/01/2014.

Date of Publishing: 18/01/2014 